\title{
Preconcentration of Lutetium from Aqueous Solution by Transcarpathian Clinoptilolite
}

\author{
Emilia Stechynska, ${ }^{1,{ }^{*}}$ Volodymyr Vasylechko, ${ }^{1,2}$ Galyna Gryshchouk ${ }^{1}$ \\ and Ihor Patsay ${ }^{1}$ \\ ${ }^{1}$ Department of Analytical Chemistry, Ivan Franko National University of Lviv, \\ Kyryla and Mefodiya Str., 6, 79005 Lviv, Ukraine; \\ ${ }^{2}$ Department of Natural Sciences and Environment Protection, Lviv University of Trade and Economics, \\ Samchuka Str., 9, 79011 Lviv, Ukraine \\ *Corresponding author: E-mail: milliast10@gmail.com
}

Received: 05-02-2019

\begin{abstract}
Sorptive properties of Transcarpathian clinoptilolite towards trace amounts of Lu(III) were studied under dynamic conditions. It is shown that this lanthanide is sorbed from the weakly alkaline solution $(\mathrm{pH} 10)$ most efficiently. The sorption capacity of clinoptilolite under the optimal conditions is equal to $9.37 \mathrm{mg} \mathrm{g}^{-1}$. The distribution of various species of $\mathrm{Lu}(\mathrm{III})$ in aqueous solutions at various total concentration of the lanthanide in the $\mathrm{pH}$ range from 4 to 13 was calculated. The best desorbent of $\mathrm{Lu}(\mathrm{III})$ is the $1 \mathrm{~mol} \mathrm{~L}^{-1}$ solution of $\mathrm{NaCl}$, preacidified with the solution of $\mathrm{HCl}$ to a value of $\mathrm{pH}$ 4.0. This desorbent enables $95-100 \%$ of $\mathrm{Lu}(\mathrm{III})$ removal. The method of $\mathrm{Lu}(\mathrm{III})$ trace amounts preconcentration from aqueous samples in a solid phase extraction mode with the further determination of this rare earth element via the spectrophotometric method using arsenazo III was developed. The linearity of the proposed method was observed in the range of 1-12 $\mathrm{ng} \mathrm{mL}^{-1}$ with the detection limit of $0.4 \mathrm{ng} \mathrm{mL}^{-1}$.
\end{abstract}

Keywords: Sorption; lutetium; clinoptilolite; solid phase extraction; dynamic conditions.

\section{Introduction}

Nowadays lanthanides (Ln) are widely used in many innovative industrial processes: for the preparation of constant magnets, catalysts, powerful lasers, magnetic alloys, and also in machine engineering, radioelectronics, chemical industry, nuclear power, cosmetology, and medicine. ${ }^{1-6}$ That is why the wastes of these metals cause a danger of natural waters contamination, which can lead to a potential risk for the whole environment.

Unlike many other heavy metals, Ln are not considered the priority environmental contaminants. However, it is known that they cause negative consequences for the human health. ${ }^{7}$ That is why the determination of $\mathrm{Ln}$ in natural waters is important not only from the point of view of analytical chemistry, but also geochemistry, oceanography, and natural science. ${ }^{8-12}$

Ln are present in natural objects in small quantities, so often the preliminary treatment of samples is applied for their determination, which in particular includes preconcentration, separation, and exclusion. ${ }^{13-16}$
The sufficient number of highly sensitive and selective methods of analysis for the detection and quantitative determination of $\mathrm{Ln}$ is not available. Among the available methods the sorption should be highlighted due to its simplicity, high efficiency, and low cost. But in the last years the solid phase extraction method with the application of different sorbents has been widely used. This method is in demand even during the sample analysis with such selective and highly sensitive methods as atomic absorption and inductively coupled plasma. ${ }^{17}$

There are papers in which the sorption capacity of various nanomaterials (namely metallic, metallic and mixed oxide, magnetic, carbonaceous, silicon, and polymer-based nanomaterials) as efficient sorbents for the preparation of samples before the bioanalysis was investigated, ${ }^{18}$ as well as the hybrid nanoadsorbents based on $\mathrm{SiO}_{2}$ and highly stable nanoparticles $\gamma-\mathrm{Fe}_{2} \mathrm{O}_{3}-\mathrm{SiO}_{2}$, that do not behave as adsorptive materials, but function as crystallization nuclei for rare earth elements (REEs) in the form of hydroxides. ${ }^{19}$ 
Authors ${ }^{20}$ presented the results of $\mathrm{Lu}(\mathrm{III})$ accumulation by the Gram-negative bacteria, and in paper $^{21}$ the adsorption of REE with the application of biosorbents was studied.

Natural zeolites are the perspective sorbents for the preconcentration of heavy metals. ${ }^{22-28}$ They are the oxide nanomaterials with the ordered structure, ${ }^{29-30}$ which can sorb trace quantities of substances, possess high sorption capacity and selectivity and are resistant to aggressive media.

The goal of this work is to study the sorptive properties of Transcarpathian clinoptilolite towards trace amounts of lutetium in aqueous solutions and to investigate the possibility of this natural sorbent application in a solid phase extraction method.

\section{Materials and Methods}

The clinoptilolite from the deposit in the village of Sokyrnytsia in Ukrainian Transcarpathia that contains 85-90 \% (mass fraction) of the main component was used for the analysis. Its specific surface area, determined by water sorption, is equal to $59 \mathrm{~m}^{2} \mathrm{~g}^{-1}$. ${ }^{31}$ The clinoptilolite formula in the oxide form (mass fraction) is as follows: $\mathrm{SiO}_{2}-67.29 \% ; \mathrm{Al}_{2} \mathrm{O}_{3}-12.32 \% ; \mathrm{TiO}_{2}-0.26 \% ; \mathrm{Fe}_{2} \mathrm{O}_{3}-$ 1.26\%; $\mathrm{FeO}-0.25 \% ; \mathrm{MgO}-0.99 \% ; \mathrm{CaO}-3.01 \% ; \mathrm{Na}_{2} \mathrm{O}-$ $0.66 \% ; \mathrm{K}_{2} \mathrm{O}-2.76 \% ; \mathrm{H}_{2} \mathrm{O}-10.90 \%{ }^{32}$ According to literature $^{33}$, the pattern of natural Transcarpathian clinoptilolite samples was indexed in a monoclinic lattice (space group $C 2 / m$ ) with the lattice parameters $a=17.64 \AA, b=17.90 \AA$, $c=7.40 \AA, \beta=116.5^{\circ}$. Clinoptilolite samples are characterized with rather broad distribution of pores size with the radii values in the range of $1-18 \mathrm{~nm}$ with the clearly expressed maximum in the $2.2-2.4 \mathrm{~nm}$ range. The energy distribution function of water thermodesorption from the Transcarpathian clinoptilolite surface is described by an asymmetric curve with the maximum near $35 \mathrm{~kJ} \mathrm{~mol}^{-1}$. $^{34}$ The difference between the numeric values of sorption characteristics of specific clinoptilolite samples taken from the same batch of sorbent was between $2-3 \%$. If the zeolite samples were used from different batches, then the results of sorption investigations differed less then by $5 \%$. During the implementation of the experimental part of this article the zeolite samples from the same batch were applied.

All reagents were of analytical grade. Standard aqueous solutions of lutetium nitrate (concentration was 1.0 $\mathrm{mg} \mathrm{mL} \mathrm{m}^{-1}$ ) were prepared by dissolving the metallic lutetium $(99.9 \%$ purity) in nitric acid (1:1). The working solutions of $\mathrm{Lu}(\mathrm{III})$ were prepared by the dilution of the standard solution. The $0.05 \%$ solution of Sulfarsazene was prepared using $0.05 \mathrm{~mol} \mathrm{~L}^{-1}$ aqueous solution of $\mathrm{Na}_{2} \mathrm{~B}_{4} \mathrm{O}_{7}$, all other reagent solutions - using bidistillate.

The sorption properties of clinoptilolite towards $\mathrm{Lu}(\mathrm{III})$ were studied with the dynamic method in a solid phase extraction mode. The solution of $\mathrm{Lu}(\mathrm{III})$ salt was passed through a cartridge for preconcentration filled with the sorbent using the peristaltic pump at a flow rate of 5 $\mathrm{mL} \mathrm{min}{ }^{-1}$. The clinoptilolite with a grain size of $0.20-0.31$ $\mathrm{mm}$ was used. The investigation techniques under dynamic conditions are described in detail in paper. ${ }^{35}$ The passage point of lutetium(III) was registered spectrophotometrically using the reaction that leads to a formation of orange complex of lutetium(III) with Sulfarsazene. Sulfarsazene changes its color from yellow to orange starting from the lutetium(III) concentration of $100 \mathrm{ng} \mathrm{mL}^{-1}$. This gave the opportunity to determine the passage moment of $\mathrm{Lu}(\mathrm{III})$ using the $\mathrm{DR} / 4000 \mathrm{~V}(\mathrm{HACH})$ spectrophotometer at $540 \mathrm{~nm}$.

The desorption of $\mathrm{Lu}(\mathrm{III})$ preconcentrated on clinoptilolite was carried out by passing $10 \mathrm{~mL}$ of a desorbent solution through the preconcentration cartridge with a flow rate of $0.5 \mathrm{~mL} \mathrm{~min}^{-1}$. The eluate was collected in a 10 $\mathrm{mL}$ volumetric flask. As preacidified solutions of alkali metals are the efficient desorbents of $\mathrm{Lu}(\mathrm{III})$ from clinoptilolite, then the solutions obtained after the desorption of $\mathrm{Lu}$ (III) contain much higher concentration of metals that are constituents of the sorbent than the matrix solutions obtained after $\mathrm{Lu}(\mathrm{III})$ sorption on clinoptilolite. That is why the selectivity of $\mathrm{Lu}(\mathrm{III})$ spectrophotometric determination with Sulfarsazene proved to be not enough during the analysis of eluates obtained after the desorption of $\mathrm{Lu}$ (III). So, in order to determine the content of desorbed $\mathrm{Lu}(\mathrm{III})$ in a solution, the spectrophotometric technique based on arsenazo III was applied that despite being less sensitive is much more selective than the technique with the application of Sulfarsazene. In order to eliminate the interfering influence of metal ions that are washed from the zeolite by the desorbent, the Rochelle salt $\left(\mathrm{C}_{4} \mathrm{H}_{4} \mathrm{O}_{6} \mathrm{~K}\right.$ $\mathrm{Na} \times 4 \mathrm{H}_{2} \mathrm{O}$ ), ascorbic acid, and sulfosalicylic acid were additionally added to the system. The solutions absorbance was measured at $\lambda=650 \mathrm{~nm}$ on the $\mathrm{DR} / 4000 \mathrm{~V}$ ( $\mathrm{HACH})$ spectrophotometer.

\section{1. Method of Lu(III) Spectrophotometric Determination with Arsenazo III}

$2 \mathrm{~mL}$ of just-prepared 1\% solution of ascorbic acid were added to $10 \mathrm{~mL}$ of the investigated solution ( $\mathrm{pH} \sim 1)$. After 2 min $4 \mathrm{~mL}$ of $5 \%$ sulfosalicilic acid solution, $1 \mathrm{~mL}$ of $0.05 \mathrm{~mol} \mathrm{~L}^{-1}$ EDTA solution, $2 \mathrm{~mL}$ of $5 \%$ potasium-sodium tartrate solution, $1 \mathrm{~mL}$ of the formic buffer solution with $\mathrm{pH} 3.5,4 \mathrm{~mL}$ of $0.05 \%$ arsenazo III solution were mixed and the $\mathrm{pH}$ value was adjusted to $2.6 \pm 0.1$, then transferred to a $25.0 \mathrm{~mL}$ volumetric flask, mixed and the absorbance of the colored solution was measured at $\lambda=650 \mathrm{~nm}$. As a blank the solution was used that contains all components except Lu(III) (the solution of „idle” experiment).

In order to build the calibration graph a certain amount of Lu(III) standard solution was poured instead of the investigated solution considering that concentrations 
of $\mathrm{Lu}(\mathrm{III})$ in final solutions are equal to $0.1 ; 0.2 ; 0.4 ; 0.6$; $0.8 ; 1.0 ; 2.0 \mu \mathrm{g} \mathrm{mL}^{-1}$.

The sorption and desorption studies were conducted at a temperature of $20 \pm 1^{\circ} \mathrm{C}$. Sorbent for the preconcentration cartridge was prepared as follows: the natural Transcarpathian clinoptilolite was grained in a ball-mill; a zeolite fraction with a grain size of $0.20-0.30 \mathrm{~mm}$ was taken, washed with distilled water and dried at room temperature to air-dry condition. To prepare the preconcentration cartridge the amount of the prepared sorbent of $0.6 \mathrm{~g}$ was used. Clinoptilolite samples were calcinated at the respective temperature for $2.5 \mathrm{~h}$ in a drying oven WSU 200 (Germany) and muffle furnace SNOL 7.2/1100 (Lithuania). The sorbent was cooled in a desiccator.

\section{Results and Discussion}

The sorption of $\mathrm{Lu}(\mathrm{III})$ on clinoptilolite depending on the solution acidity was studied (Fig. 1). The necessary $\mathrm{pH}$ values of lutetium salt solutions were adjusted by adding the diluted solutions of $\mathrm{NaOH}$ or $\mathrm{HNO}_{3}$. The results obtained prove that $\mathrm{Lu}(\mathrm{III})$ is sorbed most efficiently from the weakly alkaline solutions. On the curve showing this dependence a clear maximum at $\mathrm{pH} 10.0$ is observed.

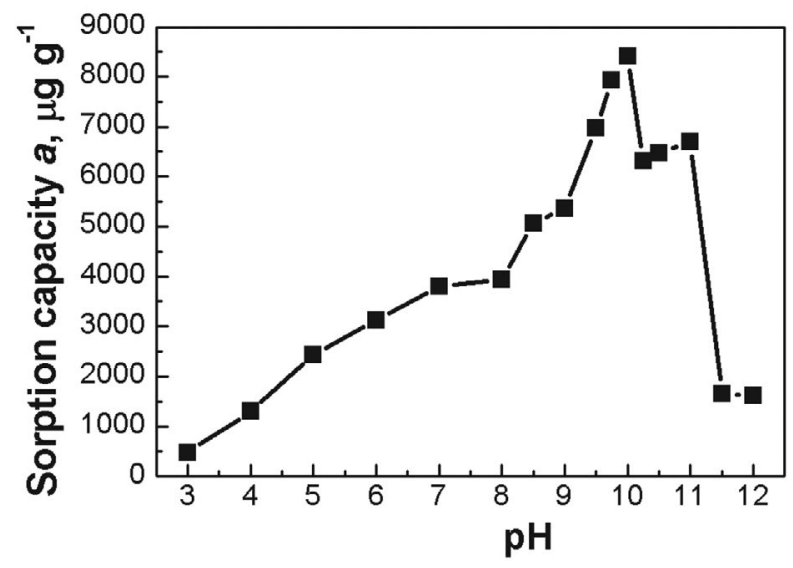

Fig 1. Dependence of sorption capacity of clinoptilolite towards $\mathrm{Lu}^{3+}$ ions on the $\mathrm{pH}$ value of the aqueous solution under dynamic conditions. $C\left(\mathrm{Lu}^{3+}\right)=1.0 \mu \mathrm{g} \mathrm{mL}^{-1}$.

It was established that the sorption capacity of Transcarpathian clinoptilolite depends on the concentration of $\mathrm{Lu}(\mathrm{III})$ in the solution (Table 1). Probably, different sorptive capability of the zeolite towards low and high concentrations of $\mathrm{Lu}(\mathrm{III})$ is due to the different ability to form hydroxo-complexes at low and high concentrations.

It is known ${ }^{26,31,33}$ that mainly the surface $\mathrm{OH}$-groups of Transcarpathian clinoptilolite are the sorption-active centers towards heavy metal ions. In our opinion, such mode of $\mathrm{Lu}(\mathrm{III})$ sorption process is caused by the chemical peculiarities of clinoptilolite surface and by existing forms
Table 1. Dependence of the sorption capacity of clinoptilolite towards $\mathrm{Lu}$ (III) on the concentration (clinoptilolite thermally activated at $50^{\circ} \mathrm{C}$; time of heat treatment $-2.5 \mathrm{~h} ; \mathrm{pH}$ of $\mathrm{Lu}(\mathrm{III})$ solutions $=$ 10.0)

\begin{tabular}{cc}
\hline $\begin{array}{c}\text { Concentration of } \\
\mathbf{L u}(\mathbf{I I I}), \boldsymbol{\mu} \mathbf{~ m L}^{\mathbf{- 1}}\end{array}$ & $\begin{array}{c}\text { Sorption capacity of clinoptilolite } \\
\text { towards } \mathbf{L u}(\mathbf{I I I}), \boldsymbol{\mu g ~ g ~}^{\mathbf{- 1}}\end{array}$ \\
\hline 0.25 & 6395 \\
0.5 & 6545 \\
1.0 & 9365 \\
2.0 & 6915 \\
5.0 & 2750 \\
10.0 & 1400 \\
\hline
\end{tabular}

of $\mathrm{Lu}(\mathrm{III})$ in aqueous solutions at different $\mathrm{pH}$. The dissociation of surface hydroxo-groups of the sorbent that first of all are responsible for heavy metals sorption from solutions, is almost completely inhibited at low $\mathrm{pH}$ values, which is the reason for the small value of clinoptilolite sorption capacity towards $\mathrm{Lu}(\mathrm{III})$. It is known that anionic forms are not sorbed on the zeolite, that is why the sorption capacity of clinoptilolite at high $\mathrm{pH}$ values is low. At the same time, on increasing $\mathrm{pH}$ from 3.0 to 10.0 the dissociation of surface $\mathrm{OH}$-groups enhances and at the same time the sorption value increases and $\mathrm{Lu}(\mathrm{III})$ species in the solution changes too.

Nowadays the hydrolysis of $\mathrm{Lu}(\mathrm{III})$ is studied poorly. We have calculated the distribution of $\mathrm{Lu}(\mathrm{III})$ in aqueous solutions in the $\mathrm{pH}$ range from 4 to 13 at different total concentrations of the metal ion (Fig. 2, 3; Tables 2, 3).

The system of equations that describes equilibria of $\mathrm{Lu}(\mathrm{III})$ hydrolysis is the following:

$$
\begin{aligned}
& \boldsymbol{K}_{11}=\frac{\left[\mathbf{L u O H}^{2+}\right]\left[\mathbf{L u}^{+}\right]}{\left[\boldsymbol{L u}^{3+}\right]}, \\
& \boldsymbol{K}_{12}=\frac{\left[\boldsymbol{L u}(\boldsymbol{O H})_{2}{ }^{+}\right]\left[\boldsymbol{H}^{+}\right]^{2}}{\left[\boldsymbol{L u}^{3+}\right]}, \\
& \boldsymbol{K}_{14}=\frac{\left[\boldsymbol{L u}(\boldsymbol{O H})_{4}^{-}\right]\left[\boldsymbol{H}^{+}\right]^{4}}{\left[\boldsymbol{L u}^{3+}\right]}, \\
& \boldsymbol{K}_{15}=\frac{\left[\boldsymbol{L u}(\boldsymbol{O H})_{5}{ }^{2-}\right]\left[\boldsymbol{H}^{+}\right]^{5}}{\left[\boldsymbol{L u}^{3+}\right]}, \\
& \boldsymbol{K}_{16}=\frac{\left[\boldsymbol{L u}(\boldsymbol{O H})_{6}{ }^{3-}\right]\left[\boldsymbol{H}^{+}\right]^{6}}{\left[\boldsymbol{L u} \boldsymbol{u}^{3+}\right]}, \\
& \boldsymbol{C}_{\boldsymbol{M}}=\left[\boldsymbol{L u}^{3+}\right]+\left[\mathbf{L u O H}{ }^{2+}\right]+\left[\boldsymbol{L u}(\mathrm{OH})_{2}{ }^{+}\right]+\left[\boldsymbol{L u}(\mathrm{OH})_{4}{ }^{-}\right]+ \\
& +\left[\boldsymbol{L u}(\mathrm{OH})_{5}{ }^{2-}\right]+\left[\boldsymbol{L u}(\mathrm{OH})_{6}{ }^{3-}\right]+\left[\mathbf{L u}(\mathrm{OH})_{3}\right], \\
& \boldsymbol{K}_{S} \geq\left[\boldsymbol{L u}^{3+}\right]\left[\boldsymbol{O H}^{-}\right]^{3}
\end{aligned}
$$

During the calculations it was assumed that total neutral hydroxide $\mathrm{Lu}(\mathrm{OH})_{3}$ (if it is actually formed) exists in a solution and the formation of a solid phase is not observed. 
As it was not clear if the formation of $\mathrm{Lu}(\mathrm{OH})_{3}$ takes place or not (is the $K_{\mathrm{s}}$ condition fulfilled), then the solution of equations system was carried out in two stages.

At first it was assumed that the condition of $\mathrm{Lu}(\mathrm{OH})_{3}$ formation is not fulfilled, so the equilibrium state was calculated assuming that $\left[\mathrm{Lu}(\mathrm{OH})_{3}\right]=0$. At this stage the equilibrium concentration of $\mathrm{Lu}^{3+}$ form were found for each $\mathrm{pH}$ value. Then the condition of the neutral hydroxide formation $\left(\left[\mathrm{Lu}^{3+}\right] \cdot\left[\mathrm{OH}^{-}\right]^{3} \geq K_{\mathrm{s}}\right)$ was checked for each $\mathrm{pH}$ value. If the condition was fulfilled, the solution of equations system was carried out taking into consideration the expression for $K_{\mathrm{s}}$ and the equilibrium concentration of $\mathrm{Lu}(\mathrm{OH})_{3}$ was also determined. The averaged values of constants found at low ionic strength of the solution were used for this purpose. ${ }^{36-40}$

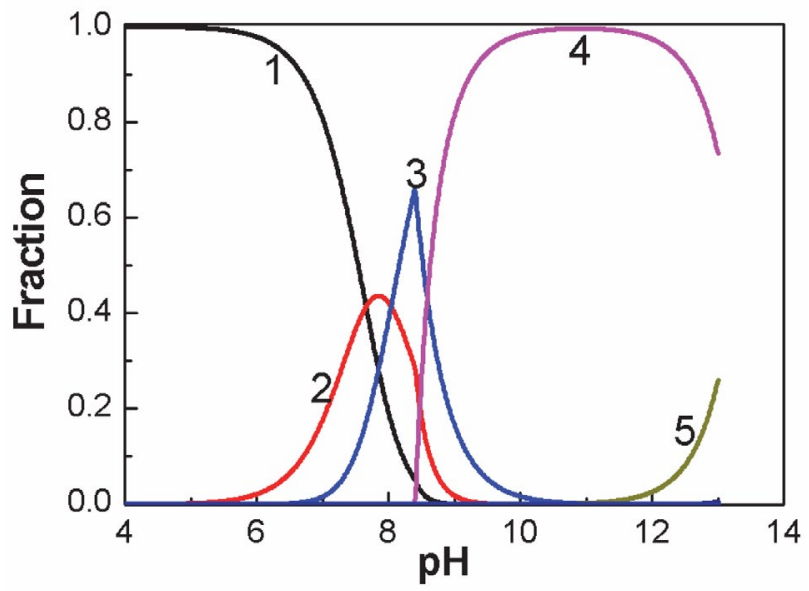

Fig 2. Dependence of the $\mathrm{Lu}(\mathrm{III})$ species fraction on $\mathrm{pH}$, concentration of $\mathrm{Lu}(\mathrm{III})$ is $1.43 \cdot 10^{-6} \mathrm{~mol} \mathrm{~L}^{-1}: 1-\mathrm{Lu}^{3+}, 2-\mathrm{LuOH}^{2+}, 3-$ $\mathrm{Lu}(\mathrm{OH})_{2}{ }^{+}, 4-\mathrm{Lu}(\mathrm{OH})_{3}, 5-\mathrm{Lu}(\mathrm{OH})_{4}^{-}$

Table 2. Dependence of the $\mathrm{Lu}(\mathrm{III})$ species fraction on $\mathrm{pH}$, concentration of $\mathrm{Lu}(\mathrm{III})$ is $1.43 \cdot 10^{-6} \mathrm{~mol} \mathrm{~L}^{-1}$

\begin{tabular}{lccc}
\hline Fraction & $\mathbf{p H ~ r a n g e s}$ & $\mathbf{p H}_{\text {max }}$ & $\mathbf{W}_{\text {max }}, \%$ \\
\hline $\mathrm{Lu}^{3+}$ & $\ldots-8.64$ & $<4.66$ & 100 \\
$\mathrm{LuOH}^{2+}$ & $5.30-9.31$ & 7.85 & 43.6 \\
$\mathrm{Lu}(\mathrm{OH})_{2}{ }^{+}$ & $6.79-10.40$ & 8.40 & 66.0 \\
$\mathrm{Lu}(\mathrm{OH})_{3}$ & $8.41-\ldots$ & $10.25-11.56(>99 \%)$ & 99.6 \\
$\mathrm{Lu}(\mathrm{OH})_{4}{ }^{-}$ & $11.00-\ldots$ & 13.0 & 25.9 \\
$\mathrm{Lu}(\mathrm{OH})_{5}{ }^{2-}$ & $12.00-\ldots$ & 13.0 & 0.554 \\
$\mathrm{Lu}(\mathrm{OH})_{6}{ }^{3-}$ & $12.34-\ldots$ & 13.0 & $1.03 \cdot 10^{-2}$ \\
\hline
\end{tabular}

* - extreme $\mathrm{pH}$ values correspond to $1 \%$ of species maximum

Summarizing the obtained results regarding the formation and distribution of $\mathrm{Lu}(\mathrm{III})$ forms, the following conclusions can be made:

1. The $\mathrm{pH}$ range where the neutral form $\mathrm{Lu}(\mathrm{OH})_{3}$ dominates depends significantly on the total concentration of a metal - the higher it is the wider are the limits of its occurence (Fig. 4).

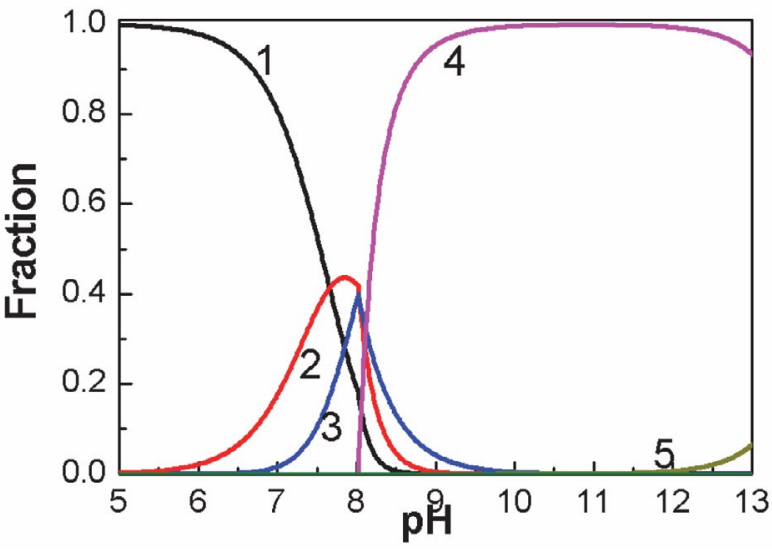

Fig 3. Dependence of the $\mathrm{Lu}(\mathrm{III})$ species fraction on $\mathrm{pH}$; concentration of $\mathrm{Lu}(\mathrm{III})$ is $5.71 \cdot 10^{-6} \mathrm{~mol} \mathrm{~L}^{-1}: 1-\mathrm{Lu}^{3+}, 2-\mathrm{LuOH}^{2+}, 3-$ $\mathrm{Lu}(\mathrm{OH})^{2+}, 4-\mathrm{Lu}(\mathrm{OH})_{3}, 5-\mathrm{Lu}(\mathrm{OH})_{4}^{-}$.

Table 3. Dependence of the $\mathrm{Lu}(\mathrm{III})$ species fraction on $\mathrm{pH}$; concentration of $\mathrm{Lu}(\mathrm{III})$ is $5.71 \cdot 10^{-6} \mathrm{~mol} \mathrm{~L}^{-1}$

\begin{tabular}{lccc}
\hline Fraction & $\mathbf{p H}{ }^{*}$ & $\mathbf{p H}_{\text {max }}$ & $\mathbf{W}_{\text {max }}, \mathbf{\%}$ \\
\hline $\mathrm{Lu}^{3+}$ & $\ldots-8.44$ & $<4,66$ & 100 \\
$\mathrm{LuOH}^{2+}$ & $5.30-9.01$ & 7.85 & 43.6 \\
$\mathrm{Lu}(\mathrm{OH})_{2}{ }^{+}$ & $6.67-10.02$ & 8.02 & 39.9 \\
$\mathrm{Lu}(\mathrm{OH})_{3}$ & $8.03-\ldots$ & $9.64-12.18(>99 \%)$ & 99.9 \\
$\mathrm{Lu}(\mathrm{OH})_{4}{ }^{-}$ & $11.00-\ldots$ & 13.0 & 6.49 \\
$\mathrm{Lu}(\mathrm{OH})_{5}{ }^{2-}$ & $12.00-\ldots$ & 13.0 & 0.139 \\
$\mathrm{Lu}(\mathrm{OH})_{6}{ }^{3-}$ & $12.34-\ldots$ & 13.0 & $2.59 \cdot 10^{-3}$ \\
\hline \multirow{2}{*}{ - extreme $\mathrm{pH}$ values correspond to $1 \%$ of species maximum }
\end{tabular}

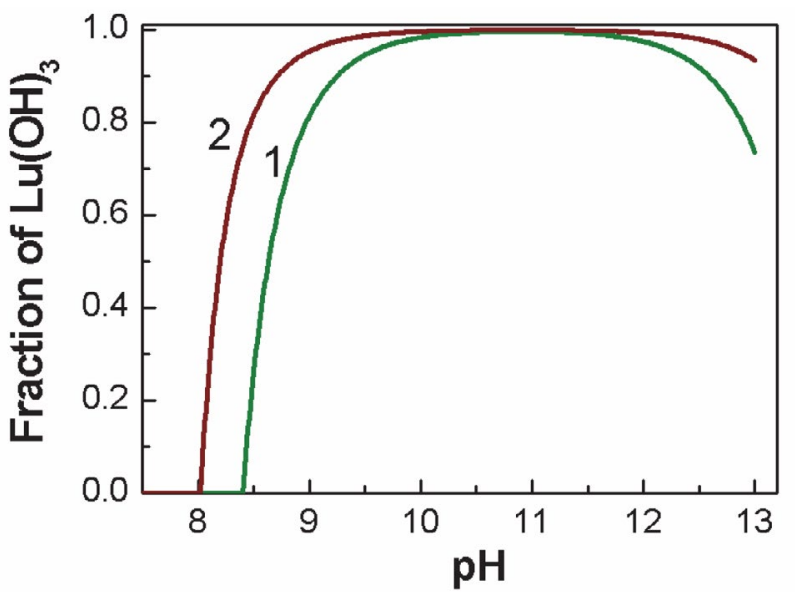

Fig 4. Dependence of the fraction of $\mathrm{Lu}(\mathrm{OH})_{3}$ on $\mathrm{pH}, 1-\mathrm{C}_{\mathrm{M}}=1.43$ $\cdot 10^{-6} \mathrm{~mol} \mathrm{~L}^{-1}, \mathrm{pH}>8.41 ; 2-C_{\mathrm{M}}=5.71 \cdot 10^{-6} \mathrm{M}, \mathrm{pH}>8.03$

2. Among the anionic forms only the species $\mathrm{Lu}(\mathrm{OH})_{4}{ }^{-}$is formed. The contribution of other ions into the $\mathrm{pH}$-distribution of the metal $\left(\mathrm{Lu}(\mathrm{OH})_{5}{ }^{2-}, \mathrm{Lu}(\mathrm{OH})_{6}{ }^{3-}\right)$ is negligible. 
3. Till $\mathrm{pH} 4.66$ metal remains in the form $\mathrm{Lu}^{3+}$. Then its fraction decreases drastically and after $\mathrm{pH}$ 8.448.64 (depending on $C_{M}$ ) this form disappears.

4. $\mathrm{pH}$-dependencies of other cathionic forms $\left(\mathrm{LuOH}^{2+}, \mathrm{Lu}(\mathrm{OH})_{2}^{+}\right)$have a shape with a pronounced peak. $\mathrm{pH}$ ranges of this species are narrower in comparison with the others. $\mathrm{pH}$ values that correspond to the maxima of these species are close.

Under the optimal sorption conditions ( $\mathrm{pH} 10.0$ ) trace amounts of Lu(III) usually exist in the soluble hydrolyzed form $\mathrm{Lu}(\mathrm{OH})_{3}$ (Fig. 2, 3). So, the sorption of Lu(III) on Transcarpathian clinoptilolite takes place under such conditions through the adsorption of the soluble neutral $\mathrm{Lu}$ (III) hydroxide on the aluminosilicate surface. Under the optimal conditions of sorption ( $\mathrm{pH} 10.0$ ) trace amounts of $\mathrm{Lu}(\mathrm{III})$ mainly exist in the hydrolyzed form $\mathrm{Lu}(\mathrm{OH})_{3}$ (Fig. 2, 3; Tables 2, 3). So, the sorption of $\mathrm{Lu}(\mathrm{III})$ on Transcarpathian clinoptilolite under such conditions mainly takes place through the adsorption of the soluble neutral Lu(III) hydroxide on the aluminosilicate surface.

In the solutions with $\mathrm{pH}$ in the range 8-10 trace amounts of $\mathrm{Lu}(\mathrm{III})$ remain in a soluble hydrolyzed form $\mathrm{Lu}(\mathrm{OH})_{3}$, as well as in cationic forms $\mathrm{Lu}^{3+}, \mathrm{LuOH}^{2+}$ and $\mathrm{Lu}(\mathrm{OH})_{2}{ }^{+}$(Fig. 2, 3; Tables 2, 3). That is why $\mathrm{Lu}(\mathrm{III})$ is sorbed from such solutions on clinoptilolite either via the adsorption of soluble neutral Lu(III) hydroxide on the clinoptilolite surface or via the ion-exchange mechanism.

The weakly alkaline ( $\mathrm{pH} 8)$, neutral and weakly acidic solutions of $\mathrm{Lu}(\mathrm{III})$ trace amounts do not contain the hydrolyzed form $\mathrm{Lu}(\mathrm{OH})_{3}$. In such solutions $\mathrm{Lu}(\mathrm{III})$ exists only in the cationic forms (Fig. 2, 3; Tables 2, 3). That is why the sorption of $\mathrm{Lu}(\mathrm{III})$ on clinoptilolite from such solutions is carried out through the ion-exchange mechanism. However the sorption capacity of clinoptilolite towards Lu(III) under such conditions is considerably lower in comparison with the optimal conditions, that is when

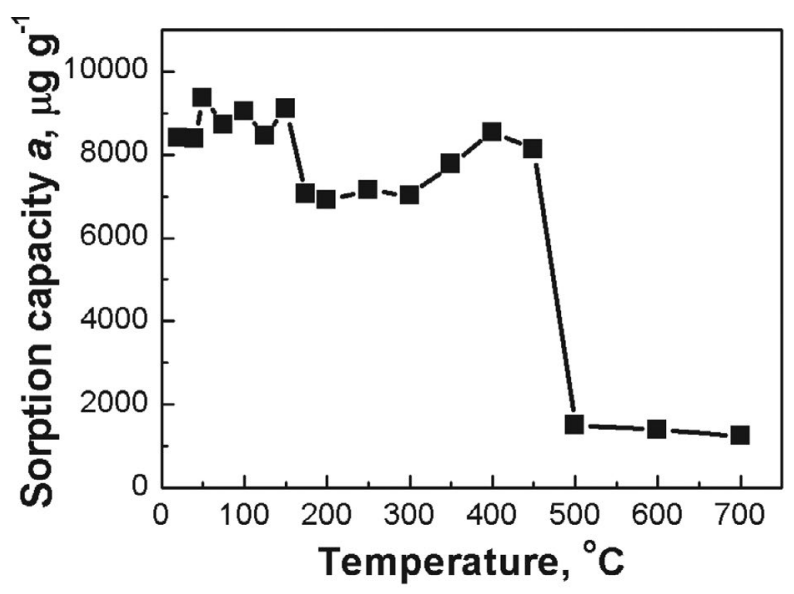

Fig 5. Dependence of the sorption capacity of clinoptilolite towards lutetium(III) on thermal treatment the sorption of $\mathrm{Lu}(\mathrm{III})$ is carried out from solutions with pH 10.0 (Fig. 1).

It is known, that sorptive properties of Transcarpathian clinoptilolite depend significantly on its preliminary thermal treatment. ${ }^{22-26,31,33,41}$

Natural clinoptilolite samples washed with distilled water were heated at different temperatures for $2.5 \mathrm{~h}$, and after cooling in a desiccator their sorption capacity towards $\mathrm{Lu}(\mathrm{III})$ ions was determined. The obtained results are presented on Fig. 5, where it can be seen that the preliminary calcination of the clinoptilolite natural form in the temperature range $50-150{ }^{\circ} \mathrm{C}$ causes the increase of sorption capacity towards $\mathrm{Lu}(\mathrm{III})$. According to ${ }^{40}$ in this temperature range the elimination of the physically adsorbed water from the clinoptilolite surface takes place.

Authors ${ }^{41}$ indicated that in the hydrated zeolite the water molecules can form cyclic hexamers using hydrogen bonds which are stabilized with oxygen atoms of the zeolite frame. That is why in such form the molecules of water do not have free $\mathrm{OH}$-groups. At temperature $200{ }^{\circ} \mathrm{C}$ during the beginning of ligand water desorption the partial destruction of hydrogen bonds takes place, that is the destruction of the cyclic hexamer, and because of that the free $\mathrm{OH}$-groups appear in that part of destructed hexamer, which remain bonded with the zeolite frame. In paper ${ }^{43}$ it was investigated, that at $300{ }^{\circ} \mathrm{C}$ the partial transformation of clinoptilolite takes place at which the number of $\mathrm{OH}$ groups in the structure of the zeolite increases according to the scheme:

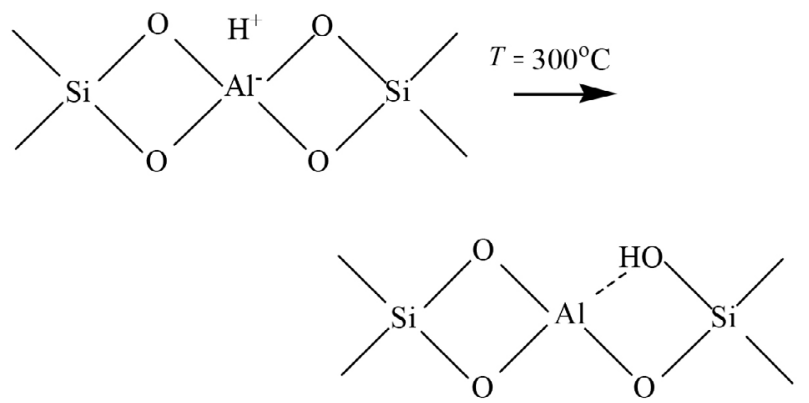

The increase of sorption efficiency of clinoptilolite samples calcinated in the temperature range $200-400{ }^{\circ} \mathrm{C}$ (Fig. 5) is due to the increase of surface $\mathrm{OH}$-groups of water molecules, and also silanol groups ( $\mathrm{Si}-\mathrm{OH})$. The sorptive properties decrease in clinoptilolite calcinated at temperatures ${ }^{3} 500{ }^{\circ} \mathrm{C}$, in our opinion, can be explained by the processes of deep dehydroxylation of the zeolite surface and its amorphization at these temperatures, which was shown in paper. ${ }^{33}$

An important stage of the work was the search of effective desorbents for lutetium. For this purpose the acidified solutions of alkali metal salts and mineral acid solutions were tested. The desorption results are given in Table 4 , testifying that the best desorbents of lutetium are the alkali metal solutions, acidified to $\mathrm{pH}$ 4.0. 
Table 4. Desorption effectiveness of Lu(III) from clinoptilolite

\begin{tabular}{|c|c|}
\hline Desorbent & $\begin{array}{c}\text { Pesorption, } \\
\%\end{array}$ \\
\hline $1 \mathrm{~mol} \mathrm{~L}^{-1} \mathrm{RbNO}_{3}$ (preacidified with $\mathrm{HNO}_{3}$ to $\mathrm{pH} 4.0$ ) & 100 \\
\hline $1 \mathrm{~mol} \mathrm{~L}^{-1} \mathrm{NaCl}$ (preacidified with $\mathrm{HCl}$ to $\mathrm{pH} 4.0$ ) & 100 \\
\hline $1 \mathrm{~mol} \mathrm{~L}^{-1} \mathrm{KCl}$ (preacidified with $\mathrm{HCl}$ to $\mathrm{pH} 4.0$ ) & 98 \\
\hline $1 \mathrm{~mol} \mathrm{~L}^{-1} \mathrm{NaNO}_{3}$ (preacidified with $\mathrm{HNO}_{3}$ to $\mathrm{pH} 4.0$ ) & 75 \\
\hline $2.0 \mathrm{~mol} \mathrm{~L}^{-1} \mathrm{HNO}_{3}$ & 60 \\
\hline $2.0 \mathrm{~mol} \mathrm{~L}^{-1} \mathrm{HCl}$ & 50 \\
\hline
\end{tabular}

$100 \%$ desorption of $\mathrm{Lu}$ from clinoptilolite is achieved with the application of $1 \mathrm{~mol} \mathrm{~L}^{-1}$ solution of $\mathrm{RbNO}_{3}$ and $1 \mathrm{~mol} \mathrm{~L}^{-1} \mathrm{NaCl}$ preacidified to $\mathrm{pH}$ 4.0. These data confirm that $\mathrm{Lu}(\mathrm{III})$ sorption on Transcarpathian clinoptilolite takes place because of the adsorption of the hydrolyzed forms of $\mathrm{Lu}(\mathrm{III})$ on the zeolite surface. For the efficient desorption of lutetium sorbed on the zeolite surface under optimal conditions the preliminary dissolution of its hydrolyzed forms with the transformation into the cationic form $\mathrm{Lu}^{3+}$ with further desorption mainly through the ion-exchange mechanism is needed. Such process is supplied by the acidified solutions of alkali metal salts (Table 4).

The influence of common ions from natural and waste waters on the preconcentration of lutetium(III) with clinoptilolite was investigated (Table 5). It is shown that the sorption of $\mathrm{Lu}(\mathrm{III})$ trace amounts on this natural sorbent takes place on the background of main macrocomponents of waters. Such contents of these cations do not influence on the maximum sorption capacity of clinoptilolite towards $\mathrm{Lu}(\mathrm{III})$ :

Table 5. The influence of common ions on the maximal sorption capacity of clinoptilolite towards $\mathrm{Lu}(\mathrm{III})\left(C_{\mathrm{Lu}(\mathrm{III})}=1.0 \mu \mathrm{g} \mathrm{mL}^{-1}\right)$

\begin{tabular}{cc}
\hline Added ion & Maximal ratio $C_{\text {ion }} / C_{\mathrm{Lu}(\mathrm{III})}$ \\
\hline $\mathrm{Na}^{+}$ & 100 \\
$\mathrm{~K}^{+}$ & 80 \\
$\mathrm{NH}_{4}^{+}$ & 30 \\
$\mathrm{Mg}^{2+}$ & 3 \\
$\mathrm{Ca}^{2+}$ & 3 \\
\hline
\end{tabular}

So, the optimal conditions for $\mathrm{Lu}(\mathrm{III})$ sorption are as follows: temperature of the preliminary thermal treatment - $50^{\circ} \mathrm{C}$; zeolite grains size of $0.20-0.31 \mathrm{~mm}$; $\mathrm{pH}-10.0$; flow rate of $\mathrm{Lu}(\mathrm{III})$ solution with the concentration of $1.0 \mu \mathrm{g} \mathrm{mL}-1-5 \mathrm{~mL} \mathrm{~min}^{-1}$. The maximal sorption capacity of clinoptilolite towards $\mathrm{Lu}(\mathrm{III})$ is equal to $9.37 \mathrm{mg} \mathrm{g}^{-1}$.

The ability of Transcarpathian clinoptilolite to sorb trace amounts of $\mathrm{Lu}(\mathrm{III})$, its high sorption capacity, the presence of the efficient desorbent give a reason to propose this sorbent for the removal of $\mathrm{Lu}(\mathrm{III})$ ions from aqueous solutions and for the preconcentration of $\mathrm{Lu}(\mathrm{III})$ during the stage of waters preparation for the analysis.

The method of Lu(III) trace amounts preconcentration in a solid phase extraction mode with further determination of this REE by using the spectrophotometric method was proposed.

\section{1. Preconcentration Method}

The sorbent was prepared as follows: the sample of natural Transcarpathian clinoptilolite was grained in a ball-mill; a zeolite fraction with a grain size of 0.20 $0.30 \mathrm{~mm}$ was taken and washed with distilled water. The dried clinoptilolite at room temperature was calcinated in a drying oven at $50^{\circ} \mathrm{C}$ for $2.5 \mathrm{~h}$. The sorbent was cooled in a desiccator. $0.25-2.0 \mathrm{~L}$ of the investigated water was acidified with nitric acid to $\mathrm{pH} \sim 1$ and heated on the sand bath for $1 \mathrm{~h}$, then filtered through the dense paper filter „blue ribbon". The solution of $\mathrm{NaOH}$ was added to the filtrate to $\mathrm{pH} \sim 10$. Then this solution was passed through the preconcentration cartridge filled with $0.6 \mathrm{~g}$ of the sorbent using the peristaltic pump with the flow rate of $5 \mathrm{~mL} \mathrm{~min}^{-1}$. After that $50 \mathrm{~mL}$ of bidistilled water were passed through the cartridge with the same flow rate. The desorption of $\mathrm{Lu}(\mathrm{III})$ was carried out in such a way: $10 \mathrm{~mL}$ of $1.0 \mathrm{~mol} \mathrm{~L}^{-1} \mathrm{NaCl}$ solution, acidified with $\mathrm{HCl}$ to $\mathrm{pH} 4.0$, were passed through the cartridge with a flow rate of $1 \mathrm{~mL} \mathrm{~min}^{-1}$. The eluate was collected in the $10.0 \mathrm{~mL}$ volumetric flask. The Lu(III) content in the solution was determined using the spectrophotometric method with arsenazo III which is described in detail in "Materials and Methods" section. The linearity of the proposed method was observed in the range of $1-12 \mathrm{ng} \mathrm{mL}^{-1}$ with the detection limit of $0.4 \mathrm{ng} \mathrm{mL}^{-1}$.

Table 6. Determination of lutetium(III) ions in the tap water with an additional introduction of Lu(III) after ions preconcentration with clinoptilolite $(\mathrm{n}=3, \mathrm{P}=0.95)$

\begin{tabular}{|c|c|c|c|c|c|}
\hline \multirow{2}{*}{$\begin{array}{l}\text { Volume of } \\
\text { tap water, } \mathrm{mL}\end{array}$} & \multirow{2}{*}{$\begin{array}{c}\text { Enrichment } \\
\text { factor }^{\mathrm{a}}\end{array}$} & \multicolumn{2}{|c|}{ Concentration of $\mathrm{Lu}(\mathrm{III}), \mu \mathrm{g} \mathrm{mL} \mathrm{m}^{-1}$} & \multirow[t]{2}{*}{ Recovery, \% } & \multirow[t]{2}{*}{ RSD, \% } \\
\hline & & Added & Found & & \\
\hline 250 & 25 & 1.00 & $0.86 \pm 0.02$ & 86 & 0.83 \\
\hline 250 & 25 & 0.50 & $0.48 \pm 0.03$ & 97 & 2.20 \\
\hline 500 & 50 & 0.50 & $0.49 \pm 0.02$ & 98 & 1.82 \\
\hline 500 & 50 & 0.25 & $0.25 \pm 0.01$ & 100 & 1.72 \\
\hline 1000 & 100 & 0.25 & $0.24 \pm 0.017$ & 96 & 2.80 \\
\hline 1500 & 150 & 0.1 & $0.095 \pm 0.007$ & 95 & 2.95 \\
\hline 2000 & 200 & 0.05 & $0.046 \pm 0.004$ & 92 & 3.06 \\
\hline
\end{tabular}


The proposed method of $\mathrm{Lu}(\mathrm{III})$ preconcentration was tested with the analysis of a tap water from the Chemical Department of Ivan Franko National University of Lviv with the additional introduction of Lu(III) ions. The results of the analysis are given in Table 6.

The results of analysis confirm the effectiveness of the proposed method of $\mathrm{Lu}(\mathrm{III})$ preconcentration in the sample preparation stage during the analysis of water, because macrocomponents practically do not influence on the removal completeness of trace amount of lutetium that was introduced into the water.

\section{Conclusions}

Sorptive properties of Transcarpathian clinoptilolite towards trace amounts of $\mathrm{Lu}(\mathrm{III})$ were studied under dynamic conditions. The optimal conditions of $\mathrm{Lu}(\mathrm{III})$ sorption are as follows: temperature of preliminary thermal treatment of the zeolite $-50{ }^{\circ} \mathrm{C}$; the flow rate of $\mathrm{Lu}(\mathrm{III})$ solution with the concentration of $1.0 \mu \mathrm{g} \mathrm{mL}^{-1}$ through the sorbent $-5 \mathrm{~mL} \mathrm{~min}^{-1}$; grain size of the zeolite $0.20-0.31$ $\mathrm{mm} ; \mathrm{pH}$ 10.0. The maximal value of Transcarpathian clinoptilolite sorption capacity towards Lu(III) under this conditions is equal to $9.37 \mathrm{mg} \mathrm{g}^{-1}$. The efficient desorbent of lutetium is the $1 \mathrm{~mol} \mathrm{~L}^{-1}$ solution of $\mathrm{NaCl}$ preacidified with $\mathrm{HCl}$ solution to $\mathrm{pH} 4$. Using this desorbent 96-100\% of lutetium preconcentrated on the zeolite can be removed.

The ability of Transcarpathian clinoptilolite to sorb either low or high concentrations, its high sorption capacity, availability of efficient desorbents give a reason to propose this common natural sorbent for the removal of $\mathrm{Lu}$ (III) ions from waters in technological solutions, and also for the preconcentration of Lu(III) ions in the stage of water preparation for the analysis.

The method of Lu(III) trace amounts preconcentration in a solid phase extraction mode during the spectrophotometric analysis of waters was proposed.

Authors' Note: The paper "Preconcentration of lutetium from aqueous solution by Transcarpathian clinoptilolite" was partially presented at the "XVI Polish-Ukrainian Symposium on Theoretical and Experimental Studies of Interfacial Phenomena and Their Technological Applications, Lublin, Poland, 28-31 August 2018”.

Acknowledgments: The author(s) disclosed receipt of the following financial support for the research, authorship, and/or publication of this article: The study was carried out with the support of the Ministry of Education and Sciences of Ukraine.

Conflicts of Interest: The authors declare no conflict of interest.

\section{References}

1. S. Handa, V. Gnanadesikan, S. Matsunaga, M. Shibasaki, Am. Chem. Soc. 2010, 132, 4925-4934. DOI:10.1021/ja100514y

2. D. Matsuura, Appl. Phys. Lett. 2002, 81, 4526-4528. DOI:10.1063/1.1527976

3. D. Haranath, S. Mishra, A.G Joshi, S. Sahai, V. Shanker, Nano-Micro Lett. 2011, 3, 141-145. DOI:10.1007/BF03353664

4. M. Pollnau, Handbook on the Physics and Chem. of Rare Earths. Bünzli J.-C.; Pecharsky V. North Holland , 2017, 51, 111-168. DOI:10.1016/bs.hpcre.2017.04.001

5. R.-N. Zhao, R. Chen, S Sun, Y.-J. Zhang, Y.-H. Yuan, J. Mol. Struct. 2017, 1141, 600-606.

DOI:10.1016/j.molstruc.2017.04.013

6. Hisao Yamashita, Sadanori Igari, Yu Iino, Appl. Radiat. Isot. 1960, 8(2-3), 111-112. DOI:10.1016/0020-708X(60)90076-4

7. F. Zereen, V. Yilmaz, Z. Arslan, Microchem. J. 2013, 110, 178184. DOI:10.1016/j.microc.2013.03.012

8. A. Fisher, D. Kara, Anal. Chim. Acta 2016, 935, 1-9. DOI:10.1016/j.aca.2016.05.052

9. K. Pyrzynska, A. Kubiak, I. Wysocka, Talanta. 2016, 154, 15-22. DOI:10.1016/j.talanta.2016.03.022

10. F. Zhao, E. Repo, Y. Meng, X. Wang, D. Yin, M. Sillanpää, J. Colloid and Interface Sci. 2016, 465, 215-224.

DOI:10.1016/j.jcis.2015.11.069

11. Q. Fu, L. Yang, Q. Wang, Talanta 2007, 72, 1248-1254. DOI:10.1016/j.talanta.2007.01.015

12. I. Çelik, D. Kara, C. Karadaş, A. Fisher, S. J. Hill, Talanta 2014, 134, 476-481. DOI:10.1016/j.talanta.2014.11.063

13. S. U. Yesiller, A. E. Eroğlua, T. Shahwan, J. Ind. Eng. Chem. 2015, 19, 898-907. DOI:10.1016/j.jiec.2012.11.005

14. T. Pasinli, A. A. Eroğlu, T. Shahvan, Anal. Chim. Acta. 2005, 547, 42-49. DOI:10.1016/j.aca.2005.04.076

15. O. I. M. Ali, H. Osmana, S. Sayeda, Shelbie, M. J. Hazard. Mater. 2011, 195, 62-67. DOI:10.1016/j.jhazmat.2011.08.014

16. R. A. Cranea, D. J. Sapsford, Chem. Eng. J. 2018, 345, 126137. DOI:10.1016/j.cej.2018.03.148

17. A. Negrea, A. Gabor, C. M. Davidescu, M. Ciopec, P. Negrea, N. Duteanu, A. Barbulescu, Sci. Rep. 2018, 8:316, 1-11. DOI:10.1038/s41598-017-18623-0

18. M. Ahmadi, H. Elmongy, T. Madrakian, M. Abdel-Rehim, Anal. Chim. Acta 2017, 958, 1-21.

DOI:10.1016/j.aca.2016.11.062

19. E. P. Legaria, J. Rocha, C.-W. Tai, V. G. Kessler, G. A. Seisenbaeva, Sci. Rep. 2017, 7:43740, 1-13.

DOI: $10.1038 /$ srep 43740

20. T. Tsuruta, J. Rare Earths 2007, 5:25, 526-532. DOI:10.1016/S1002-0721(07)60556-0

21. N. K.Gupta, A. Gupta, P. Ramteke, H. Sahoo, A. Sengupta, J. Mol. Liq. 2018, 274, 148-164.

DOI:10.1016/j.molliq.2018.10.134

22. V. O. Vasylechko, E. T. Stechynska, O. D. Stashkiv, G. V. Gryshchouk, I. O. Patsay, Acta Physica Polonica A 2018, 133(4), 794-797. DOI:10.12693/APhysPolA.133.794

23. V. O. Vasylechko, G. V. Gryshchouk, V. P. Zakordonskiy, I. O. Patsay, N. V. Len', O. A. Vyviurska, Micropor. Mesopor. Mat. 2013, 167, 155-161. DOI:10.1016/j.micromeso.2012.08.021 
24. V. O.Vasylechko, G. V. Gryshchouk, V. P. Zakordonskiy, O. A. Vyviurska, A. V. Pashuk, Chem. Central J. 2015, 9, 1:45, 1-7. DOI:10.1186/s13065-015-0118-z

25. V. O. Vasylechko, G. V. Gryshchouk, V. P. Zakordonskiy, L. O. Vasylechko, M. Schmidt, I. M. Leshchack, Ya. M. Kalychak, S. R. Bagday, Talanta 2017, 174, 486-492.

DOI:10.1016/j.talanta.2017.06.052

26. V. Vasylechko, G. Gryshchouk, M. Derev'yanko, Ya. Skorobahatyj, O. Tymoshuk, Visnyk Lviv Univ. Ser. Chem. 2008, 49, 170-179.

http://prima.Inu.edu.ua/faculty/Chem/visnyk_2008/

ANALIT/05_Vasylechko.pdf

27. M. Sprynskyy, M. Lebedynets, A. P. Terzyk, P. Kowalczyk, J. Namieśnik, B. Buszewski, J. Colloid and Interface Sci. 2005, 284, 408-415. DOI:10.1016/j.jcis.2004.10.058

28. M. Sprynskyy, T. Ligor, M. Lebedynets, B. Buszewski, J. Hazard Mater. 2009, 169, 847-854.

DOI:10.1016/j.jhazmat.2009.04.019

29. L.-H. Chen, X.-Y. Li, , J. C. Rooke, Y.-H. Zhang, X.-Y. Yang, Y. Tang, B.-L. Su, J. Mater. Chem. 2012, 22, 17381-17403.

DOI:10.1039/c2jm31957h

30. M. E. Davis, Nature 2002, 417, 813-821.

http://image.sciencenet.cn/olddata/kexue.com.cn/bbs/ upload/15327Ordered_porous_materials_for_emerging applications.pdf?fbclid=IwAR0DwCETn6MbCOpRnN7_ wJlQvC_tsq6umG9bwqJNIsdq2z27cGsUs5ViMgc

DOI:10.1038/nature00785

31. V. O. Vasylechko, G. V. Cryshchouk, L. O. Lebedynets, Yu. B. Kuz'ma, L. O. Vasylechko, V.P Zakordonskiy, Adsorp. Sci. Technol. 1999, 17(2), 125-134.

DOI:10.1177/026361749901700206
32. Y. I. Tarasevich, V. E. Polyakov, V. Zh. Penchev, G. N. Kirov, Kh. I. Minchev, I. G. Polyakov, L. I. Badekha, Khim. Technol. Vody 1991, 13(2), 132-140.

33. V. O. Vasylechko, G. V. Gryschouk, Yu. B. Kuz'ma, V. P. Zakordonskiy, L. O. Vasylechko, Lebedynets, M. B. Kalytotovs'ka, Micropor. Mesopor. Mat. 2003, 60, 183-196.

DOI:10.1016/S1387-1811(03)00376-7

34. V. P. Zakordonskiy, V. O. Vasylechko, P. Staszczuk, G. V. Gryshchouk, Visnyk Lviv Univ. Ser. Chem. 2004, 44, 247-256. http://ua.convdocs.org/docs/index-239615.html

35. V. O. Vasylechko, L. O. Lebedynets, G. V. Cryshchouk, Yu. B. Kuz'ma, L. O. Vasylechko, T. M. Bernats'ka, Adsorpt. Sci. Technol. 1996, 14(5), 267-277.

\section{DOI:10.1177/026361749601400501}

36. L. N. Usherenko, N.A. Skorik, Zh. Neorgan. Khim. 1972, 17(11), 2918-2921.

37. E. Rizkalla, G. Choppin, in: Gshneider K.; Jr. and L. Eyring (Eds.) Handbook of Physics and Chemistry of Rare Earth. Elsevier. Amsterdam, 1991, 15, 393-442. DOI:10.1016/S0168-1273(05)80009-1

38. U. Frolova, V. Kumok, V. Serebrennikov, Izvestiya VUZ USSR Khim \& Khim Technol. 1966, 9(2), 176-179.

39. V. A. Nazarenko, V. P. Antonovich, Ye. M. N'evskaya, Hydrolysis of metal ions in dilute solutions. Atomizdat. Moscow, 1974.

40. C. F. Baes, R. E. Mesmer, The Hydrolysis of Cations; John Wiley \& Sons : New York - London - Sidney - Toronto, 1976.

41. V. O. Vasylechko, G. V. Gryshchouk, I. I. Polyans'ka, Yu. B. Kuz'ma, Polish J. Chem. 2008, 82, 1-2, 443-451.

42. J. Hunger, I. A. Beta, H. Böhlig, L. Chris, H. Jobic, B. Hunger, Phys. Chem. B. 2006, 110(1), 342-353.

DOI:10.1021/jp054636u

43. B. Tomazović, T. Ćeranić, G. Sijarić, Zeolites 1966, 16, 301308. DOI:10.1016/0144-2449(95)00118-2

\section{Povzetek}

Pod dinamičnimi pogoji smo preučevali sorpcijske lastnosti transkarpatskega klinoptilolita za Lu(III) v sledovih. Pokazali smo, da se ta lantanid najbolj učinkovito sorbira iz šibko alkalnih raztopin ( $\mathrm{pH} 10)$. Sorpcijska kapaciteta klinoptilolita pri optimalnih pogojih je enaka $9,37 \mathrm{mg} \mathrm{g}^{-1}$. Izračunali smo porazdelitev različnih zvrsti Lu(III) v vodni raztopini pri različni skupni koncentraciji lantanida v pH območju 4 do 13. Najboljši desorbent za Lu(III) je 1 mol L ${ }^{-1}$ raztopina $\mathrm{NaCl}$, nakisana $\mathrm{z}$ raztopino $\mathrm{HCl}$ do $\mathrm{pH} 4,0$. Ta desorbent omogoča 95-100 \% odstranitev Lu(III). Razvili smo tudi metodo za predkoncentracijo Lu(III) v sledovih iz vodnih vzorcev v načinu ekstrakcije na trdno fazo z nadaljnjo določitvijo tega redkozemeljskega elementa s spektrofotometrijsko metodo ob uporabi reagenta arsenazo III. Linearnost predlagane metode smo pokazali v območju $1-12 \mathrm{ng} \mathrm{mL}^{-1} \mathrm{z}$ mejo zaznave $0,4 \mathrm{ng} \mathrm{mL}^{-1}$.

Except when otherwise noted, articles in this journal are published under the terms and conditions of the Creative Commons Attribution 4.0 International License 